\title{
The Indian Ocean Scenario in the 14th Century Latin Crusade Tract: Possibilities of a World Historical Approach
}

\author{
Ranabir CHAKRAVARTI \\ Jawaharlal Nehru University \\ New Delhi, India \\ ranabirchsjnu@gmail.com
}

\section{Abstract}

The paper examines, in the light of current historiography, the recent trends in the application and applicability of the World Historical studies on the Indian Ocean scenario. Calling for the combination of the breadth of the World Historical studies with the analysis of a historical scenario in its specific spatio-temporal context-instead of a synchronic approach-the present study takes a close look at commerce and politics in the western Indian Ocean in the light of an early 14th century Latin Crusade tract, How to Defeat the Saracens by William of Adam (Guillelmus Ade, Tractatus quomodo Sarraceni sunt expugnandi), a Dominican friar. The text offers remarkable insights into the interlocking of the Indian Ocean and the South Asian subcontinent with the Mamluk Sultanate, the Ilkhanid realm and the Crusades. The paper argues for what is now termed as braided and connected histories. 


\section{Key words}

Indian Ocean, Indian subcontinent, Red Sea, Mamluk Sultanate, Ilkhanate, Crusade, maritime trade, maritime contestations

\section{PROLOGUE}

The World Historical approach and methodology have been attracting the practitioners of pasts largely because of the breadth of such enquiries. By going beyond the confines of the relatively modern constructs of the nation state, continents and area studies World History offers stimulating possibilities and exercises in braided and connected histories which are perhaps more complex than comparative histories. In comparative history, the benchmark often is a developed, complex, industrialized entity, the historical experiences of the development of which is put to comparison with similar or dissimilar situations for demonstrating the consonance or contrasts in historical trajectories. World History as a conceptual tool and category is of relatively recent origin and also of a loose structure; the loose or less rigorous formulations of its disciplinary boundaries is not perhaps a weakness, but actually a strength as it can accommodate diverse and competitive historiographical positions, with little compulsions in limiting the enquiries within a nation state. The approach may be fruitful in analyzing pasts of areas/countries where the experiences of a nation state are relatively recent. The case in point here could be many new nation states in Asian, African and Latin American contexts which did witness complex state societies and also simpler pre-state societies in their protracted pasts, and were not bereft of linkages and connections with diverse communities, both neighboring and far away. It is true that the world historical model has some affinities to the understanding of the world-system analysis, taking the cue from Wallerstein's celebrated formulations. ${ }^{1}$ As a result of this, a large

${ }^{1}$ Immanuel Wallerstein, The Modern World-System, 4 vols. (New York: Academic Press, 1974-2011). 
number of world historical exercises relate principally to the socio-economic and political experiences of the post-150o CE days which witnessed the emergence and consolidation of the capitalist system. ${ }^{2}$

The breadth of the world historical studies, far beyond the limits of a state and or a nation state, may have an important bearing on maritime studies where the maritime spacewhether a sea or an ocean-is not characterized by the firm and fixed boundaries of a continental or land-based entity; even where there is a politico-sovereign claim over a maritime space, the boundaries are invariably porous. This is particularly applicable in the case of the Indian Ocean which is noted for its very long tradition of seafaring and human interactions across a vast maritime space over several millennia. Most of the countries associated with the Indian Ocean are populous and have a long history, but with relatively recent experiences of nation states. The understanding of the Indian Ocean ethos in historical terms is crucial to the grasping the evolving past of these countries which came under the clutches of European colonial empires during the span of nearly five centuries (1500-1900). ${ }^{3}$

\section{Problems OF PERSPECTIVES: WORLD HistORICAL APPROACHES TO THE INDIAN OCEAN STUDIES}

One needs, however, to take into account that the synthesization of historical knowledge and experiences are essential for giving the World Historical flavor to the history-writing processes. The breadth of the perspective for this kind of a study often compels a historian to prefer a synchronic treatment of a historical subject or theme, to a diachronic one which often renders a

${ }^{2}$ Immanuel Wallerstein, "Incorporation of the Indian Subcontinent in the Capitalist World Economy," in The Indian Ocean, Explorations in History, Commerce, and Politics, ed. Satish Chandra (New Delhi: Sage, 1987), 222-52.

${ }^{3}$ For an overview of the maritime perspective of the Indian Ocean see M. N. Pearson, The Indian Ocean (London; New York: Routledge, 2003). Pearson very cogently argues that the Indian Ocean history cannot be confined to merely the 1500-1800 phase and there is a longer and connected history of the Indian Ocean before the advent of north Atlantic powers, companies and empires in this maritime space during the 1500-1800 phase. 
historical research with spatial and temporal specificities. Though the synchronic approach is often fraught with stimulating formulations, there can occasionally emerge problem(s) of perspective.

A case in point is Polard's projection of the Naturalis Hisotria (NH) of Pliny (late first century $\mathrm{CE}$ ) as a text advocating 'botanical imperialism' in the context of the Roman empire's territorial expansion and commercial outreach. ${ }^{4}$ Pliny's $\mathrm{NH}$ is seen by Polard as an attempt at cataloguing animals, plants, minerals, alien lands and peoples-in other words, catering to the curiosity of the imperial authority. For Polard, the Templum Pacis and the Horrea Pipperataria signified the imperial design to know and thereby control the exotic. The mention of Vespasian's garden in the Templum Pacis, according to Polard, not only speaks of the Roman curiosity, but was an example of a 'colonial botanical garden' where transplantation of trees from elsewhere and growing these non-local plants on Italian soil were done under imperial aegis. The construction of the Horrea Piperateria manifested an intention to assert direct economic control of the Roman emperor over the distribution of the exotic spices from the East, including the black pepper. Polard's reading of the Naturalis Historia as a discourse on Roman ideological and economic imperialism thus situates the Templum Pacis and Horrea Piperataria as major components of that discourse. This she then tries to locate in the World Historical studies as, according to her, the majority of the world-systems and global analyses studies relate to the capitalist societies since 1500 CE. She strongly argues for pushing these models to much earlier epochs, including the days of the Roman Empire. Polard, therefore, finds little dissimilarity between 19th century England's dependence on China tea and Rome's dependence on imported pepper. Both imperial powers, in her view, wasted huge amount of currency to the Orient, without the capability of offering any desirable commodities to the East in exchange of the coveted Oriental luxuries. This kind of an exercise will hardly be beneficial to World Historical stud-

${ }^{4}$ Elizabeth Ann Polard, "Pliny's Natural History and the Flavian Templus Pacis: Botanical Imperialism in the First Century CE Rome,” Journal of World History 20, no. 3 (September 2009): 309-38. 
ies, which are her prime academic objectives, since the author, in her enthusiasm for pushing the World History methodologies to pre-1500 CE days and conditions, completely ignores the diachronic approach. Her synchronic approach sees little difference, especially in terms of political economy, between an ancient empire and a modern colonial empire emerging out of industrial revolution. Polard shows little awareness that the Roman Empire's trading interests in the East, especially with the subcontinent, never resulted in the restructuring of the subcontinent's economy to further the political economy of the metropolitan area of the Roman Empire in the early centuries CE.

Without, however, promoting a World History analysis for the trade between the Roman Empire and the subcontinent in the early centuries CE, Grant Parker highlights the importance of luxury commodities across vast continental and maritime spaces as the principal engine of long-distance commerce. Parker seems to add to this analysis a culturalist position by underlining the culture of consumption, especially among the elites of the Roman Empire, that would sustain this vast trading operations and initiatives. Parker brings this culture of consumption, especially the taste for luxury, exotic and rare commodities, to the centre stage of the demands for Indian textiles (including the famous muslin), spices (pepper), gems (pearl and diamond) among the Roman elites and sees it as the driving force in the trade between the Roman empire and India. ${ }^{5}$ Conspicuous consumption being an urban phenomenon, Parker presents the literary evidence of Rome's position as the premier consumer city in the Mediterranean world. Rome was a megalopolis with a population of nearly a million, interacting in many complex ways with the economies of the hinterland. Put differently, Parker discerns that the culture of consumption and the taste of fine worldly goods, not only in Rome itself but also in different areas in the Mediterranean, acted as the principal engine for Rome's reaching out to the subcontinent for trade.

In other words, the initiatives and capabilities of the remarkable long-distance trade between the Roman Empire and 
the subcontinent belonged, according to him, to the people from the Mediterranean. First, one cannot but hear a reverberation of Warmington's celebration of the primacy of Western initiatives in finding out the Indian Ocean and the subcontinent, now a dated and virtually discarded position. ${ }^{6}$ Second, without at all belittling the demands for Indian/Oriental luxuries, it is pertinent here to enquire into the nature of these luxuries. The black pepper of Kerala was indeed a coveted luxury at the Mediterranean and the Red Sea ports and cities; but it was not a luxury at the place of its origin. In Malabar, the black pepper was a floral product, grown in the hilly areas and in bulk. Whether the Malabar coastal society too viewed it as an item of conspicuous consumption, leading to a cultured and refined life-style, is a problematic which is neither addressed nor explored by Parker. Excessive thrust on and search for luxuries in Parker's analyses, therefore, does not allow him to look at the textual references to the daily necessity items, including ordinary cotton cloth and grains, being shipped out from Barygaza (modern Broach in $\mathrm{Gu}$ jarat) to ports across the Arabian Sea, both in the Persian Gulf and the Red Sea zones. $^{7}$ Since the available Classical sources stress much on the import of coveted Eastern luxuries, exploring

${ }^{6}$ E. H. Warmington, The Commerce between Roman Empire and India (1928; repr., London: Luzac, 1974).

${ }^{7}$ This is particularly borne out by The Periplus Maris Erythraei, trans. and ed. Lionel Casson (Princeton, N. J.: Princeton University Press, 1989), sections 14:59, 36:73, 39:75, 48:81 and 51:83; in these sections impressions of long-distance overseas trade in grain, rice, ghee (clarified butter), seasame oil., cotton cloth—mostly, coarse variety-dates and indigo are available. Also see Ranabir Chakravarti, introduction to Trade in Early India, ed. Chakravarti (New Delhi; New York: Oxford University Press, 2005); also Ranabir Chakravarti, "Examining the Hinterland and the Foreland of the Port of Muziris in the Wider Perspective of the Subcontinent's Long Distance Network," in Muziris, Imperial Rome, and the Indian Ocean ed. K. S. Mathew (forthcoming). The crucial role of the Red Sea port of Berenike in this trade network is now well established. See, W. Z. Wendrich , R. S. Tomber, S. G. Sidebotham, J. A. Harrell, R. T. J. Cappers, and R. S. Bagnall "Berenike Crossroads: The Integration of Information," Journal of the Economic and Social History of the Orient 46, no. 1 (2003): 46-87; also Steven E. Sidebotham and Willemina Z. Wendrich, "Berenike: Archaeological Fieldwork at a Ptolemaic-Roman Port on the Red Sea Coast of Egypt, 199498," Sahara 10 (May 1999): 84-96; Steven E. Sidebotham and Willemina Z. Wendrich, "Berenike: Archaeological Fieldwork at a a Ptolemaic-Roman Port on the Red Sea Coast of Egypt, 1999-2001," Sahara 13 (July 2002): 23-50. I am most grateful to Professor Sidebotham for kindly sending me these two papers. Also Steven E. Sidebotham, "An Overview of Archaeological Work in the Eastern Desert and along the Red Sea Coast by the University of Delaware-Leiden University 1987-1995,” in A Gateway from the Eastern Mediterranean to India, ed. Mary Boussac and J. F. Salles (New Delhi: Manohar, 2005). 
the possibilities of maritime and long-distance trade in bulk, staple items has remained in the margins in current historiography.

\section{SITUATING THE 14th CENTURY CRUSADE TRACT AND ITS AUTHOR}

In the light of the above historiographical trends and perspectives, or more precisely the problems of perspectives, we would like to attempt here the combining of the breadth of the World Historical exercises with the specificities of a particular situation in a spatio-temporal context of a maritime scenario. The case in point is the fourteenth century Western Indian Ocean scenario in the light of a Latin crusade tract. We hope to demonstrate here how the tools of World Historical studies may have bearings on highlighting an Indian Ocean scenario. The text is Tractus quo modo Sarraceni sunt expugnadi by Guillelmus Ade (How to Defeat the Saracens by William of Adam). ${ }^{8}$

The Indian Ocean had already become a regularly frequented maritime zone much before the advent of the Portuguese in the late fifteenth century. Vasco da Gama's voyage from Malindi to Calicut cannot, therefore, be judged as a marker of the 'age of discoveries' in the Indian Ocean. The Indian Ocean scenario in the early fourteenth century is lit up by this Crusade propaganda literature. One remembers that with the fall of Acre in 1291 the control of the Latin Christendom over the Holy Land was finally over. But the Crusade mentality was by no means terminated, it lingered on for quite some time when many propaganda texts were written by both clergy and lay people with a view to urging another round of Crusades and hoping for ultimate Christian victory and recovery. The papal authority too encouraged the submission of such texts and tracts. ${ }^{9}$ To this genre

${ }^{8}$ William of Adam, How to Defeat the Saracens [Tractatus quomodo Sarraceni sunt expugnandi. English \& Latin], trans. Giles Constable; in collaboration with Ranabir Chakravarti, Olivia Remie Constable, Tia Kolbaba and Janet M. Martin (Washington D. C.: Dumberton Oaks, 2012).

${ }^{9}$ A. S. Atiya, The Crusade in the Later Middle Ages (London: Methuen, 1938); Atiya, Crusades, Commerce, and Culture (Bloomington: Indiana University Press, 1962); Atiya, The Crusades: Historiography and Bibliography (Bloomington: Indiana University Press, 1962); Carole Hillebrand, The Crusades: Islamic Perspectives (London: Routledge, 2000). 
belongs our tract that demands a close scrutiny. The tract was written by Bishop Guillelmus Ade (William of Adam), possibly a French, in the first half of the fourteenth century. ${ }^{10}$ His primary aim was, of course, to suggest practicable means to win a victorious war against the Egyptian/Mamluk sultan and to finally recover/re-establish Christian control over the Holy Land which the Latin Christendom had lost in 1291. He, however, brings the Indian Ocean scenario in his scheme of things, giving his advice a distinct stamp of individuality and uniqueness among similar propagandist texts, as the Indian Ocean had no direct bearing on the question of Crusade. This is the most distinctive feature of the Crusade treatise in question, without a parallel in other similar Crusade tracts. " This remarkable linking of the Crusade question with the Indian Ocean scenario by our 14th century author calls for an in-depth analysis which may have a relevance to World Historical studies.

Bishop William of Adam was born in Antivari in $1275 \mathrm{CE}$ and subsequently became a Dominican Friar. He was assigned to various places in the East, e.g. Smyrna (a major port in the Aegean Sea), Constantinople, Syria, and Sultanieh (in Persia under Ilkhanid/Ilkhanate rule). At the last mentioned place he once was a Bishop, and later became the Archbishop. He traveled from Iran to India and then across the Arabian Sea to Ethiopia. He was also assigned to visit Armenia, but whether the visit to Armenia materialized is not clear. He probably died in Avignon in France in 1341 where he spent a considerable time during the last phase of his life. This brief biographical sketch of Guillaume Adam provides the background of the composition of his tractate, its most significant aspect being his understanding and per-

${ }^{10}$ My most grateful thanks to Professor Dietmar Rothermund who first drew my attention to this tractate. I wish to record my indebtedness to Professor Avrom Udovitch of Princeton University and Professor Giles Constable of the Institute for Advanced Study, Princeton for their valuable help in my study of this text.

${ }^{11}$ The treatise has been utilized and analyzed by Charles F. Beckingham, "The Quest for Prester John,” in Between Islam and Christendom (London: Variorum Reprints, 1983), Article II. But Beckingham paid little attention to the Bishop's linking of the Indian Ocean commerce with the material and political eminence of Mamluk Sultanate, the most distinctive feature of this treatise. Beckingham's study was based on the first published edition of the Crusade text available in Recueil des Hitroriens des Croisades: Documents armeniens, 2 vols. Charles Kohler ed., (Paris: Imprimerie Nationale, 1906), 2:475-515. 
ception of the East, obviously from the point of view of the Latin Christendom. It is difficult to pinpoint the exact date of the tract which seems to have been written around 1316-17. The fundamental proposition the Bishop laid down is the ways and means to recover the Holy Land from Saracenic occupation and control. This required the defeat and subjugation of Egypt at the hands of the Latin Christendom. His tract is devoted to the ways of extermination of the Muslim Mamluk Sultanate which he considered an uphill task for the Latin Christendom in the early fourteenth century in the light of the relatively weaker situation in the Christendom. The unique feature of his argument is his thrust on impoverishing Egypt before inflicting a military defeat on it. ${ }^{12}$ The author was fully aware of the immense importance of Egypt in the maritime trade network of both the Mediterranean and the Indian Ocean.

\section{THE BISHOP'S PERCEPTION OF THE INDIAN OCEAN NETWORK AND THE CRUSADE QUESTION}

Ever since the advent of the Fatimid caliphate in 969 with its capital at al Fustat (Old Cairo), Egypt or Masr emerged as the western terminus of the Indian Ocean maritime trade. Needless to explain that Egypt's geography provided it with the crucial integration with the Mediterranean Sea also. There is a well known and voluminous literature on the seemingly imperishable commercial linkages between Egypt and the Italian city states in the middle ages, especially during the Crusades. Without going into the details of this profusely documented history of Mediterranean commerce between the Italian cities and Egypt, it will suffice to say that Guillaume Ade was fully conscious of this trade. He categorically accuses the Christian merchants-the Catalans, Venetians, Pisans and especially, the Genoese-of systematically flouting all sanctions of maritime blockade imposed by the Latin Christendom on trade with the Islamic ruler of Egypt. He also highlights the insatiable profit motive of these Italian merchants

${ }^{12}$ See Introduction by Giles Constable to the English translation of the tract, cited in footnote 8 . 
who because of their love for gain hardly cared for any fear of excommunication. So, William of Adam strongly advocates the employment of a fleet in the Mediterranean to block all maritime trade with Egypt so that the merchants are prevented from supplying the Mamluk ruler with food, weapons and materials of all sorts.

The second part of his advice seeks to forbid all pilgrims to go to the Holy Land, as the Sultan was extracting substantial resources in the form of pilgrimage tax. His third advice is to capture, if necessary, Constantinople and bring it under the control of Latin Christendom, because Constantinople had been, among other things, too friendly to the Sultan of Egypt and supplying Egypt with provisions and slaves. He further follows it up with the recommendation for reaching an alliance with the Ilkhanid Mongol rulers of Persia, who (perhaps for overthrowing the Abbasid Caliphate in 1258) were perceived as willing collaborators of the Latin Christendom in the design for the doom of the Mamluk Sultanate. The establishment of a 'see' at Sultanieh in Ilkhanid Persia in the early fourteenth century and the presence of Guillaume Ade there assume a special significance in this context. The fifth and last part of his recommendation concerns the Indian Ocean scenario, located far away from the Mediterranean. ${ }^{13}$ This last section is perhaps the most original and significant aspect of his advice and has a direct bearing on the topic of our discussion. An elaborate statement and analysis will be in order here.

Unlike other Christian authors of similar propagandist literature, directed against the Mamluk Sultan of Egypt, Guillelmus Ade very strongly argues that Egypt's commercial pre-eminence could not be curbed by merely policing the Mediterranean and the Genoese merchants in particular. He underlines the importance of the Indian Ocean trade for contributing to the prosperity and pre-eminence of Egypt and speaks of the shipping of many coveted commodities from India to Egypt from where these were further exported to Italian cities, their preferred destination. ${ }^{14}$ How and how much he was aware of the Indian 
Ocean commerce and its bearing on the crusade politics will be evident from his observation that "No one questions how great a profit the Saracens of Egypt derive from India." 15

India figures in his text as

Truly and effectively, and not casually or occasionally, the source of all evils which I described above. ${ }^{16}$

By seeing India as the ultimate evil he implied India contributed to the strength and prosperity of Egypt which he proposed to heavily reduce as a major step towards gaining victory in crusade.

For of all the things that are sold in Egypt, such as pepper, ginger and other spices, and precious stone; silk and those precious materials dyed with the colors of India; and all other precious things are carried from India to Egypt. ${ }^{17}$

In a remarkable metaphor with different parts of the body, which he presents as a simile to the body of commerce, the bishop says

For as food goes from the head through the throat, and from the throat into the stomach and from the stomach to the other parts of the body, so the aforesaid precious goods originate from the Indian sea, as from head, and are spread through the Gulf of Eden (Aden), as by the throat, from there by the Red Sea to Egypt, as to the stomach, and then, as to the other parts of the body, to the other parts of the world. ${ }^{18}$

To teach Egypt a lesson by disrupting its trade with India he suggests

If someone were to cut off the head, and therefore, the whole stomach would consequently suffer from the lack of food and the other members would perish ... The remedy of the disease is therefore to be applied to the place from which the evil comes. This will occur if that route can in some way be blockaded so that goods from the

\footnotetext{
${ }^{15}$ Ibid., 97.

${ }^{16}$ Ibid., 99.

${ }^{17}$ Ibid., 101.

18 Ibid.
} 
shores of the Indies cannot come through the Gulf of Aden to Egypt; since if this Gulf is closed there would be no other place or approach by which the Egyptians could obtain the goods for which our men sail to Alexandria. ${ }^{19}$

According to him, everything that was sold in Egyptpepper, ginger, spices, precious stones, silk and dyed clothreached there from India. William of Adam compared the export of Indian commodities to Egypt with the transfer of food from the head (capita; literally head, but actually meaning the mouth) to the throat (guttur) wherefrom it reaches the stomach (stomachum) which provides the nourishment to the whole body. He graphically compares the Indian Sea with the head/mouth (mari Indico quasi a capite). He seems to have actually implied mouth through which food enters human body. From the Indian Sea the victuals of commerce, as it were, then would enter the Gulf of Eden which to him functioned as the throat (Gulfum Eden quasi per guttur) and which facilitated the transportation of commodities to Egypt; Egypt in its turn carries the metaphor of stomachum (Egiptum quasi in stomachum) that helps nourish the entire body. He further proceeds to say that the head, i.e. the Indian Sea, should be severed from the stomach or Egypt, by interrupting or cutting off the maritime supply line-the throat-like Gulf of Eden. He then presents an image of a withering stomach unable to nourish other limbs. Thus decayed, Egypt's economy would be in ruins and its military superiority would logically collapse. That, in the argument of the Bishop, would be the opportune moment to strike Egypt with the final blow from the Latin Christendom.

\section{The Pre-History of NAVAL BlOCKADE AND THE EXTENT OF AD- VERSARIAL SITUATION IN THE INDIAN OCEAN PRIOR TO 1500 CE}

This demonstration of the causality of the Indian Ocean commerce for the prosperity of Mamluk Egypt is an outstanding feature of the arguments of the propagandist author, emerging out 
of his first hand experiences in this part of the world. This is particularly borne out by his specific prescription of the way to cut off the capita from the guttur. The capita or the head/mouth, according to Adam, is the Mare Indico, an expression which had surfaced first in the Naturalis Historia of Pliny in late first century CE. This Indian Sea certainly refers to the Arabian Sea and has a close correspondence with al bahr al Hindi (The Sea of India) figuring frequently in the works of travel and geography by Muslim authors. The striking expression is of course the Gulf of Eden, the guttur in Adam's perception. Its role as a passage between the Indian Sea and Egypt makes the Gulf of Aden and/or the Red Sea (the bahr al Qulzum of thirteenth century Arab texts) the ideal candidate for identification. The expression Gulf of Eden, based obviously on a slight but significant change of the name Aden-the premier port on the southern end of the Red Sea-is intended to provide a distinct Biblical hue to this famous port in the Islamic world. Our author proposes to impose a naval blockade on the ingress and egress into the port of Aden by maintaining a fleet of galleys at Socotra, an island 500 miles southeast of Aden and at a distance of 300 miles from al Mukalla, the principal port in the Hadhrami coast. The name Socotra is derived from Sanskrit Dvipa Sukhadhara (Isle of the Abode of Bliss), clearly suggesting its commercial and cultural linkages with mainland South Asia. The importance of this island looms large in the celebrated fifteenth century navigational manual of Ibn Majid who knew it as Suqutra. ${ }^{20}$ As it was impossible for the Papal authority to ensure a direct blockade of Egyptian ports like Alexandria, Qus or Aidhab by controlling the northern part of the Red Sea, the author suggests an alternative means of blockading the outstanding port, Aden, and an entry point in the southern extreme of the same sea-lane, that is the island of Socotra. He therefore presents Socotra as a choke point. The

${ }^{20}$ Ibn Majid's manual on navigation is available in English. G. A. R. Tibbetts, trans., Arab Navigation in the Indian Ocean before the Coming of the Portuguese (London: Royal Asiatic Society of Great Britain and Ireland, 1974). The regular visits of Indian merchants, shippers and sailors to Socotra during the first five centuries of the CE are now wonderfully captured by Ingo Strauch, Foreign Sailors on Socotra (Bremen: Hempen Verlag, 2012). Significantly enough, the epigraphic records of these visits clearly show that the island was a place of sojourning for seafarers. It is only in the perception and design of William of Adam that Socotra for the first time looms large as a strategic point in blockading the Gulf of Aden. 
blockade would be exercised by bringing a fleet of galleys from Hormuz, the premier port at the opening of the Persian Gulf; Hormuz, therefore, would emerge as another choke point in his scheme.

With this end in view, William of Adam strongly advocates an alliance between Latin Christendom and Ilkhanid Mongol rulers on his perception that Mamluk Egypt would be the common enemy for both. This is a point that deserves a closer scrutiny here. In the well known history of the Crusades, the Christians lost the control over Jerusalem in 1187 when Saladin scored a major victory over the Latin Christendom in the battle of Hattin that also helped Saladin gain some foothold over Acre and greater parts of Jerusalem. However, it was a short-lived Saracenic victory, as Acre was wrested back by the Christians under their fold in 1191. Acre then remained the capital of Jerusalem under Christian control and occupation for the next one hundred years. Religious orders of the Latin Christendom had their headquarters near Acre from where emanated crucial military and diplomatic efforts and operations. The advent of the Mamluk Sultanate in Egypt in 1250 witnessed the emergence of a more formidable adversary of the Latin Christendom than the erstwhile Ayyubid power, largely on the basis of the invincibility of the heavy cavalry of the Mamluks. The Mamluk Egypt had already come into conflict with the Latin Christendom in 1261, only a decade after its foundation. The decisive Mamluk onslaught on the Latin Christendom took place in 1291 when occurred the siege and eventually the fall of Acre. ${ }^{21}$

No less interesting a political development was the collapse of the mighty Abbasid power with its citadel at Baghdad in 1258 before the Ilkhanate or Ilkhanid Mongols. The Ilkhanate or Ilkhanid Mongols stood as a breakaway state of the massive Mongol empire, established in the early thirteenth century by Ghenghis Khan. Founded by Ghenghis Khan's grandson Hulagu Khan, the Ilkhanid power drew its strength largely from the Ghenghis Khan's sweeping military victories over the Khwarzmian realm during the 1219-24 CE period. Even before bringing the curtain down upon the Abbasid Caliphate Hulagu had al- 
ready crushed the Ismaili Nizari Hashshashians in 1256. In fact, he was entrusted with the subduing of the Muslim realms as far as Egypt. At the peak of his power, Hulagu Khan's authority swayed over Iran, Iraq, Turkemenistan, Armenia, Azerbaizan, Georgia, Turkemenistan and Afghanistan. It is no surprise that this new power in Iran and Iraq would come into conflict with the emerging power of the Mamluks of Egypt. The Ilkhanid Mongol realm, having an ally in the Yuan dynasty of China, was systematically and in a sustained manner opposed to the Mamluks who were common enemies of both the Latin Christendom and the Ilkhanid Mongols. The Ilkhanid Mongols were already defeated by the Mamluks in 1260 in the battle of Ain Jalut. This sustained adversarial situation between the Mamluks and the Ilkhanid Mongols seems to have been viewed by the Latin Christendom as a possible source of alliance between them and the Ilkhanid Mongols against their common enemy, the Mamluk Sultanate. The Latin Christendom could have been encouraged by the Ilkhanid's sympathetic attitudes to Buddhism and Christianity; Hulagu, interestingly enough, had a Christian wife, Doquz Khatun. In this context are to be appreciated the several attempts towards the formation of a Franco-Mongol alliance (Frank being the common denomination in the Islamic world for western European powers) against the Mamluks during the 13th and 14th centuries. However, this united opposition to the Mamluks was not sufficient to curb the military and political might of the Egyptian Sultanate. The only military victory of the Mongols over the Mamluks was the short-lived success in the battle of Wadi al-Khazandar, lasting for a mere few months. ${ }^{22}$

This brief overview of the political scenario in West Asia and north Africa in the second half of the thirteenth century, especially in the circumstances of the fall of Acre in 1291, may explain William of Adam's ambitious plan of cultivating the Ilkhanid Mongol realm by the Latin Christendom to diplomatically isolate the Mamluk power, which in its turn, derived enormous economic advantages from maritime commerce in both the Mediterranean Sea and the Indian Ocean zone. The Bishop was

${ }^{22}$ Peter Golden, Nomads and Sedentary Societies in Medieval Eurasia (Washington DC: American Historical Association, 1998). 
clearly very well conversant with the political, military and diplomatic scenario in the Mediterranean, North Africa and West Asia not only about the immediate past since the fall of Acre in 1291, but also the protracted enmity between the Mamluks on the one hand and the Latin Christendom and the Ilkhanid Mongols on the other from the mid-thirteenth century onwards. ${ }^{23}$ Was Socotra favoured by him as the area of blockading the Gulf of Aden because of its having Christian population in a predominantly Islamic world?

To this is to be coupled the remarkable awareness of our author not only about the Indian Ocean maritime commerce, but the intimate linkages between Aden and several Indian ports. That Aden maintained sustained commercial ties with the western coast of India is well demonstrated by the Jewish geniza documents (of the 11th to 13th centuries), the travel accounts of Marco Polo and Ibn Battuta and the Chinese text, Zhu fan Zhi (1225) by Zhao ru Gua, an official supervising trade under the Song dynasty of China. ${ }^{24}$ William of Adam highlighted the importance of three Indian ports, all on the western sea-board of India. These are Collam, Tana and Cambayet. The first is undoubtedly Quilon in present day Kerala (south-western India), repeatedly figuring in Arab accounts and the Jewish documentary geniza as Kulam Mali, Mali signifying Malibar or Malabar, the name of the coastal strip of Kerala. Tana can easily be identified with Sristhanaka or Thana, a suburb of and to the north of present Mumbai. Cambayet is undoubtedly the same as the great port of Cambay (Stambhatirtha in Indian sources) in Gujarat. Cambay's strength lay in its commanding a very rich agricultural hinterland in Gujarat and also for having an extensive foreland. Adam also speaks of 'dive insulide' which could denote the Maldive islands, figuring prominently in the fifteenth century navigational manual of ibn Majid. An alternative identification may also be sought in Diu in Gujarat (the name derived from Sanskrit

${ }^{23}$ Peter B. Golden, Central Asia in World History (New York: Oxford University Press, 2011).

${ }^{24}$ Ranabir Chakravarti, "Merchants, Merchandise and Merchantmen in Western Seaboard of India: A Maritime Profile (500 BCE-1500 CE)," in The Trading World of the Indian Ocean 1500-1800, ed. Om Prakash (New Delhi: Pearson, 2012), 53-116, especially 78-85. 
Dvipa or island) which rose to great prominence under the Portuguese. Interestingly enough, a shipping network between al Div or Diu and Aden is recorded in a Jewish business letter of twelfth century. ${ }^{25}$ One tends therefore to identify dive insulide with Diu in the Gujarat coast.

First, Adam strikes us with a singular clarity and certitude about premier Indian ports on the western sea-board of India, something which is not matched by any contemporary Christian literature. This is obviously due to his received information in the course of his travels in the western Indian Ocean. Second, his choice of the Indian ports is impeccable as the four Indian ports in his accounts were particularly noted for sustained commercial linkages both with the Red Sea port of Aden and the Persian Gulf port of Hormuz. This was a crucial matter as Adam was proposing to blockade the shipping of Indian commodities through Aden with which these ports maintained thriving maritime commerce. Adam's idea was that the blockade would force a diversion of India's maritime commerce, oriented to Aden and the Red Sea, to Hormuz in Persia. This would result in the revival of maritime commerce through the Persian Gulf, but more importantly ensure the importation of coveted Indian commodities to the eastern Mediterranean through Ilkhanid Iran and the Levant. In other words, Adam saw it as a viable alternative conduit to the Red Sea passage dominated by Mamluk Egypt which would suffer serious impoverishment, eventually contributing to its military/political decay. William of Adam strikes us with his accurate information that the ports on the western sea-board of India were noted for the availability of excellent quality of timber which was essential for shipbuilding. The third significant point is that Adam never confused India with Ethiopia-a common error of perception of many Christian authors looking for Prester John.

${ }^{25}$ S. D. Goitein, "From Aden to India: Specimens of the Correspondence of India Traders of the Twelfth Century," Journal of the Economic and Social History of the Orient 23, no. 1 (1980): 43-66. Goitein pointed to the shipping network between al Dyyb (Diu) and Aden on the basis of a twelfth century CE Jewish business letter; S. D. Goitein and Mordechai A. Friedman, India Traders of the Middle Ages: Documents from the Cairo Geniza (Leiden and Boston: E. J. Brill, 2008), 316. They favor the identification of al Dyyb with Maldives. The preference for Diu as a better identification of al Dyyb is argued for in 
The vision and plan of a naval blockade to cut off the Indian commerce with Egypt via the Red Sea show the combination of Christian aspiration for a renewed Crusade against the Mamluks with a rare understanding of the Indian Ocean maritime commerce. In spite of the novelty of his ideas, this was never put to practice: which is why we consider it as a blueprint of a naval blockade. The project of forming a strong alliance between the Latin Christendom and the Ilkhanid Empire in Persia did not materialize. It raises, on the other hand, a more fundamental question regarding the perception of the Indian Ocean situation in the attitude of a Bishop from the Mediterranean world. The Mediterranean Sea is not merely a theatre of commerce, but has a long tradition of being considered as a maritime space which, like the landmass, could be brought under the politico-military superiority of a power or powers. It is in fitness of things that Romans called the Mediterranean as mare nostrum, our sea. The sea in the Mediterranean tradition and outlook was an arena fit for exercising military power with a view to establishing political mastery over the sea. The Fatimid and the Mamluk realms in Egypt, like the Byzantine Empire and the Ottoman empire of subsequent centuries, maintained their respective naval fleets in the Mediterranean, especially the eastern Mediterranean.

In sharp contrast to this, the Indian Ocean offers rare, at the most irregular, instances of a major political power maintaining a regular navy to establish its maritime superiority over the Ocean or parts thereof. Formidable political masters of the countries of the Indian Ocean region viewed the vast landmass of South Asia, West Asia, Central and East Asia as the arenas fit for campaign, conquest and political expansion. The Indian Ocean was almost never seen by these political authorities as a political theatre over which control and power needed to be exercised and demonstrated. The Indian Ocean was an arena for merchants, sailors, pirates, fisher-folk, but not marked by contestations among rulers prior to $1500 \mathrm{CE}$.

It was only during the heydays of the South Indian Chola rulers (c. 985-1120 CE) that one encounters the distinct Chola po- 
litical orientation to the Bay of Bengal. ${ }^{26}$ In the western sector of the Indian Ocean in 1134 or 1136, the rapacious ruler of Kish, an island kingdom in the Persian Gulf, launched a naval campaign against Aden with burmas (large pot-like round-hull ships), shaffaras (smaller but faster ships) and jashujiyats (small vessels meant for actual raiding). A Jewish merchant wrote a letter to inform about this event to another Jewish merchant settled in al Manjrur in Mangalore. The business letter leaves no room for doubt that the raid met with little success; it hardly affected the thriving commerce of Aden, though Ramisht, a fabulously rich ship-owner from Siraf (in the Persian Gulf) lost two ships during the troubled times. ${ }^{27}$ The contents of the two eye witness accounts may also indicate that the raid by the Sultan of Qays was not adequately equipped with proper war vessels and it actually spoke of the desperation of the ruler of Qays at the growing prosperity of Aden, rather than sustained adversarial situations between the two major sites in the western Indian Ocean. ${ }^{28}$ There are some indications that the local rulers of Aden, according to ibn al Mujawir (death $1291 \mathrm{CE}$ ), maintained sawani type of vessels to protect the visiting mercantile marine from pirates.

${ }^{26}$ The Cholas conquered Sri Lanka which was eventually turned into a Chola province till $1120 \mathrm{CE}$. The most spectacular and daring Chola maritime expedition was undertaken in 1024-25 CE when about 12 places in mainland and maritime South-east Asia were conquered; but these areas were not annexed to the Chola realm. K. A. Nilakantha Sastri, The Colas (Madras: University of Madras, 1955); Hermann Kulke, K. Kesavapany and Vijay Sukhija eds., From Nagapattinam to Suwarnadwipa, Reflections on the Chola Naval Expeditions to Southeast Asia (New Delhi: Manohar, 2010); also Hermann Kulke, "Rivalry and Competition in the Bay of Bengal and Its Bearing on Indian Ocean Studies," in Commerce and Culture in the Bay of Bengal 1500-1800, ed. Om Prakash (New Delhi: Manohar, 1999), 17-35; Ranabir Chakravarti, "The Pull Towards the Coast: Politics and Polity in India 600-1300 CE” (Presidential Address presented at the Indian History Congress, Patiala, 2011).

${ }^{27}$ Goitein and Friedman, India Traders of the Middle Ages, 437-50; S. D. Goitein, "Two Eye Witness Reports on an Expedition of the king of Kish (Qays) against Aden," Bulletin of the School of Oriental and African Studies 16, no. 2 (1954): 247-57. Roxani Eleni Margariti, "Mercantile Networks, Port Cities, and "Pirate" States: Conflict and Competition in the Indian Ocean World of Trade before the Sixteenth Century," Journal of the Economic and Social History of the Orient 51, no. 4 (2008): 543-77. Margariti argues on the basis of these two letters for the conflictual situations in the Indian Ocean much before the advent of the Portuguese. More recently Sebastian Prange, “The Contested Sea: Regimes of Maritime Violence in the Pre-modern Indian Ocean,” Journal of Early Modern History 17, no.1 (2013): 9-33. Prange has argued similarly for political contestations in the Indian Ocean. The present author does not subscribe to the positions of Margaritti and Prange.

${ }^{28}$ Ranabir Chakravarti, India and the Indian Ocean: Issues in Trade and Politics (Mumbai: Maritime History Society, 2014), 24, 31-32. 
These could have been vessels meant for warding off pirates in the area around Aden, but can hardly be considered as forming a regular navy. ${ }^{29}$ One of Bishop Adam's illustrious contemporaries, ibn Battutta, also speaks of the occasional use of vessels by a port authority for punitive actions against pirates in the western Indian Ocean. These vessels, in his account, belonged to the class of jafn/ajfan/jifan/jufun and ukayri; he indiscriminately used these terms to denote both merchant marines and combat vessels. He seems to suggest that there were no specific ships constructed for fighting in the Indian Ocean. Also, conspicuous by its absence in his account is the ghurab type of vessels which were typical war galleys active in the Mediterranean, reported by ibn Mammati (1209) and al Makrizi (1441). ${ }^{30}$ In his voluminous manual of shipping and navigation in the Indian Ocean, Ibn Majid stresses on siyasat (manner of sailing the ship) and isharat (signs like aquatic life, waves, currents, sky and constellation, certain landmarks) for a safe and successful voyage which should have been prompted by profit or gain (faida). But nowhere in the text does the author prescribe the nautical technology for seabattles, nor view the maritime space as an arena fit for establishing political power. The celebrated voyages of Zeng he (1404-33) under official patronage of the Ming Empire did reach a number of strategic points in the Indian Ocean. There are noticeable instances of violence in Southeast Asian contexts during these voyages. On the other hand, in South Asia and Western Indian Ocean scenario these voyages had little orientations to establishing naval supremacy, but were geared to tribute-taking intentions. One cannot also miss the fact that in spite of these spectacular voyages, these lasted less than three decades. ${ }^{31}$ The Indian Ocean world had neither the ideological platform nor the war machinery that could render the Bishop's blueprint of a naval

${ }^{29}$ Samuel Berret Miles, "Extract from an Arabic Work Relating to Aden, in Texts and Studies on Historical Geography and Topography of Central and Southern Arabia," collected and reprinted by Fuat Sezgin, Islamic Geography 92 (1993): 147-60.

${ }^{30}$ Dionisus Albert Agius, “Classifying Vessel-types in ibn Battuta’s Rihala,” in Ships and the Development of Maritime Technology in the Indian Ocean, ed. David Parkin and Ruth Barnes (London: Curzon, 2002), 174-208.

${ }^{31}$ Geoff Wade, "Engaging the South: Ming China and Southeast Asia in the Fifteenth Century," Journal of the Economic and Social History of the Orient 51, no. 4 (2008): 578638. 
blockade of the Red Sea trade through Socotra and Aden in the early fourteenth century into a practicable application.

\section{EPILOGUE}

The Indian Ocean for the first time tasted the experience of large scale and sustained armed trade with the advent and rise of the Portuguese almost at the turn of the sixteenth century. The intense desire of the Portuguese crown to thwart Egypt's trade with the Red Sea and South Asia for ensuring monopoly over spice trade is well known. The Portuguese did capture by 1510 Hormuz, the ideal chokepoint in the Persian Gulf, but never managed to capture and control Calicut in Malabar and Aden. On 6 March, 1506 Conquistador Afonso de Albuquerque ordered captain Tristan da Cunha to capture Socotra. Socotra was duly captured. ${ }^{32}$ For the Portuguese, it was meant to be of vital consequence as Socotra was seen by them as the ideal point to establish a blockade of the Red Sea on the one hand to prevent shipping from Calicut to Aden, and to oppose the EgyptianVenetian naval confederacy in the Red Sea, on the other. Though the Portuguese could not capture Aden, they did proceed to capture Hormuz and Oman in the Persian Gulf after they had conquered Socotra. The Bishop's blueprint was nearly realized by the Portugese after almost two centuries had elapsed. In this way, the fourteenth century tractate offers a pre-history (at least at a conceptual level) of the European designs of armed trade, commercial and colonial expansion in the Indian Ocean from the sixteenth century onwards. This involved, in other words, attempts at destroying the freedom of merchants through violence unleashed by the state on the sea. The Portuguese, the Dutch, the French and the English merchants arrived in the Indian Ocean scenario in the post-1500 phase initially for the lure of profit from trade in spices and textiles which they ardently sought to import to Europe from the Indian Ocean countries. On the other hand, the principal export of pre-industrial Europe to the

${ }^{32}$ Bailey W. Diffie and George D. Winius, Foundations of the Portuguese Empire, 1415-1580 (Minneapolis: University of Minnesota Press, 1977). 
world-including the Indian Ocean world-was violence, as Ashin Das Gupta, Niels Steensgaard and Om Prakash effectively demonstrate. ${ }^{33}$ It is possibly on this ground that $1500 \mathrm{CE}$ is considered as a watershed in the history of the Indian Ocean marking the beginning of the early modern period which lasted until 18oo, the period that has so far attracted maximum attention of the Indian Ocean historians.

${ }^{33}$ Om Prakash, "European Corporate Enterprises and the Politics of Trade in India 1600-1800," in Politics and Trade in the Indian Ocean World, Essays in Honour of Ashin Das Gupta, ed. Rudrangshu Mukherjee and Lakshmi Subramanian (New Delhi: Oxford University Press, 1998), 182; Ashin Das Gupta, The World of the Indian Ocean Merchants 1500-1800 (New Delhi: Oxford University Press, 2001). 